\title{
PENDAMINGAN PEMANFAATAN AMPAS TAHU MENJADI PRODUK PANGAN BERNILAI EKONOMI TINGGI BAGI MASYARAKAT PENGUSAHA TAHU DI GERISAK MATARAM
}

\author{
Muti'ah $^{1}$, Jeckson Siahaan ${ }^{1}$, Eka Junaidi ${ }^{1}$, dan Sukib ${ }^{1}$ \\ ${ }^{12}$ Program Studi Pendidikan Kimia, Universitas Mataram. Jalan Majapahit No. 62 \\ Mataram, NTB 83112, Indonesia. \\ * Coressponding Author. E-mail: mutiah_fkip@unram.ac.id
}

\section{Received: 28 Oktober 2021 Accepted: 4 Februari 2022 Published: 6 Februari 2022}

\begin{abstract}
Abstrak
Telah dilakukan kegiatan pengabdian pada masyarakat berupa pendampingan pemanfaatan ampas tahu menjadi produk pangan bernilai ekonomi tinggi pada masyarakat pengusaha tahu di Kampung Gerisak, Mataram. Masyarakat yang terlibat terutama adalah ibu - ibu yang tergabung dalam kelompok pengusaha tahu rumahan dengan jumlah $12-15$ orang. Kegiatan yang dilakukan adalah: penyuluhan, pembuatan kerupuk, dan diskusi-tanya jawab. Hasil kegiatan pengabdian masyarakat adalah: (1) Berhasil melakukan penyuluhan tentang cara pembuatan kerupuk dengan bahan baku ampas tahu dengan hasil masyarakat sangat tertarik dan termotivasi. (2) Berhasil dibuat kerupuk berbahan dasar ampas tahu, melalui tahapan: penyiapan bahan, pencampuran, perebusan, pemotongan, penjemuran, dan penggorengan. Hasil evaluasi oleh masyarakat menunjukkan bahwa untuk meningkatkan kualitas rasa, maka perlu ditambahkan bumbu masak seperti bawang. (3) Berhasil melaksanakan diskusi dan tanya jawab dengan hasil masyarakat termotivasi untuk membuat kerupuk tersebut dan menginginkan inovasi yang terkait dengan rasa (gurih atau pedas). Kesimpulan dari kegiatan ini menunjukkan bahwa ampas tahu dapat digunakan sebagai bahan dasar kerupuk dan masyarakat cukup tertarik dan termotivasi dengan kegiatan tersebut.
\end{abstract}

Kata Kunci: Pendampingan, ampas tahu, kerupuk

\section{PENDAHULUAN}

Lingkungan Gerisak merupakan bagian dari wilayah kelurahan Kekalik Jaya, di Kecamatan Sekarbela, Kota Mataram. Luas wilayah lingkungan Gerisak kurang lebih 17,5 Ha dengan jumlah penduduk sekitar 808 kepala keluarga (BPS, 2019). Sebagian besar penduduk di Lingkungan tersebut menjalankan usaha industri rumahan yaitu pembuatan tahu dan tempe. Berdasarkan hasil observasi didapatkan bahwa usaha tersebut sudah dijalankan secara turun temurun. Berdasarkan data di kelurahan didapatkan bahwa jumlah pengusaha tahu dan tempe ada 50 pengusaha yang terbagi dalam 20 pengusaha tahu dan atau 30 pengusaha tempe. (Dewi, M. U., 2017)

Permasalahan yang dihadapi oleh masyarakat pengrajin tahu di lingkungan Gerisak, adalah: (1) mahalnya harga kedelai di pasaran, (2) kurangnya modal, dan (3) penghasilan yang pas-pasan dari usahanya. Oleh sebab itu untuk mengatasi permasalahan tersebut dilakukan dengan menaikkan harga tahu. Hal tersebut mengakibatkan banyak tahu tidak terjual habis di pasaran. Kondisi semacam ini yang mengakibatkan semakin sulit untuk menjalani usaha industri rumahan tersebut dan beberapa industri memilih untuk menghentikan kegiatan, sehingga beberapa pengrajin beralih menjadi buruh. (Putra, Y.M.P., 2012)

Beberapa permasalahan di atas adalah terkait dengan aspek ekonomi, sementara itu dari aspek lingkungan kesehatan, kegiatan industri tahu juga memberikan dampak negatif yaitu timbulnya limbah padat dan limbah cair, (Mariatun, \& Harry I.J.,2018). Limbah padat seperti ampas tahu hingga saat ini belum secara optimum dimanfaatkan menjadi bahan yang lebih ekonomis karena hanya sebagai pakan ternak dengan harga jual murah. Menurut Dewi, R.A, (2017) ampas tahu bisa dibuat menjadi kerupuk tradisional tetapi belum bisa dijual dalam produk mentah secara nasional.

Dengan meninjau kondisi industri tahu di Kekalik Gersak, dari hasil observasi diketahui bahwa kebutuhan kacang kedelai setiap hari rata dari $50 \mathrm{~kg}$ hingga $300 \mathrm{~kg}$ tiap industri. Oleh 
karena konversi kacang kedelai menjadi ampas tahu sebesar 100-112\%, maka jumlah ampas tahu dihasilkan berkisar 60- $350 \mathrm{~kg}$ setiap hari setiap industri. Selama ini ampas tahu hanya dijual sebagai pakan ternak yang setiap kwintalnya hanya seharaga Rp 25.000. Melihat potensi limbah ampas tahu tersebut sebenarnya bisa dikembangkan menjadi usaha sampingan bagi pengrajin tahu di Gerisak, yaitu dengan memanfaatkan menjadi sumber pangan baru yang mempunyai nilai ekonomi lebih tinggi sehingga dapat untuk meningkatkan penghasilan mereka.

Ditinjau dari aspek gizi, upaya mengembangkan ampas tahu menjadi bahan baru yang berkualitas merupakan pilihan yang tepat, karena masih mengandung serat, karbohidrat, protein, lemak, asam organik, dan mineral. Melihat sifat ampas tahu yang memiliki banyak kelebihan seperti mengandung protein yang tinggi, banyak mengandung serat, serta murah dan berlimpah, maka dapat dikembangkan suatu bentuk usaha sampingan baru dengan memanfaatkan ampas tahu sebagai bahan dasarnya. Hal ini juga sebagai salah satu upaya memberikan alternatif gizi sebagai sumber protein yang bermanfaat bagi masyarakat (Pusbangtepa, 1989).

Beberapa produk pangan yang dapat dikembangkan dengan bahan baku ampas tahu antara lain kerupuk, kecap, tempe gembus, taoco, dan tepung yang dapat digunakan dalam pembuatan berbagai makanan seperti kue kering. Pada pembuatan kue dan aneka makanan, pemakaian tepung ampas tahu tersebut dapat disubstitusikan ke dalam gandum (Sayow, et al, 2020). Dengan keterbatasan waktu dan biaya maka sebagai tahap awal kegiatan pendampingan ini, maka kegiatan pemanfaatan ampas tahu hanya sebatas pada pembuatan kerupuk pastar yang diharapkan bisa mempunyai nilai jual lebih tinggi.

Berdasarkan latar belakang tersebut di atas dapat diidentifikasi beberapa permasalahan dan solusinya sebagai berikut: (1) Kesulitan pengrajin tahu Gerisak Mataram dalam menjalani usaha pembuatan tahu yang pada prinsipnya adalah rendahnya penghasilan mereka, sehingga beberapa perajin memilih untuk menghentikan kegiatan, dan beralih menjadi buruh. (2) Adanya limbah padat berupa ampas tahu dalam pembuatan tahu yang belum dimanfaatkan dengan baik, yaitu terbuang mencemari lingkungan dan bila dijual harganya sangat murah padahal ampas tahu memiliki kandungan gizi yang masih cukup bila dibandingkan dengan tahu. Disamping itu juga saat ini telah dikembangkan berbagai produk makanan yang bersumber dari ampas tahu. SOLUSI yang ditawarkan dalam mengatasi permasalahan 1 dan 2 adalah memproses ampas tahu menjadi bahan pangan yang bernilai ekonimi tinggi yang dalam hal ini adalah kerupuk ampas tahu rasa ayam(kerupuk pastar). (Secara rinci diuraikan dalam metode). (3) Pengetahuan dan ketampilan pembuatan kerupuk ampas tahu yang telah biasa dibuat selama ini perlu diinovasi menjadi kerupuk yang berkualitas baik dari warna, rasa, tekstur dan bentuk. Kerupuk pastar yang diusulkan dalam kegiatan ini diharapkan dapat memenuhi kriteria kerupuk yang diharapkan. Namun demikian sampai saat ini pengetahuan maupun ketrampilan pembuatannya bagi masyarakat pengrajin tahu Gerisak Mataram belum dimiliki. SOLUSI yang dilakukan untuk mengatasi hal tersebut adalah melakukan kegiatan penyuluhan dan ketrampilan cara pembuatan kerupuk ampas tahu rasa ayam (kerupuk pastar)

\section{METODE PELAKSANAAN}

Obyek atau sasaran dari kegiatan pengabdian ini adalah masyarakat pengrajin tahu-tempe di kampung Gerisak wilayah Kekalik Jaya, Mataram. Jumlah pengusaha tahu $20 \mathrm{kk}$ dan atau tempe $30 \mathrm{kk}$. Oleh sebab itu target/peserta kegiatan riil antara $12-15$ orang

Metode yang digunakan dalam kegiatan ini adalah pelatihan yang meliputi 2 kegiatan, yaitu : praktek pembuatan, penyuluhan dan diskusi - tanya jawab cara pembuatan kerupuk.. Secara singkat, langkah langkah penyuluan adalah: (1) menyampaikan maksud dan tujuan kegiatan, (2) membagikan contoh kerupuk pastar kepada para peserta sebagai motivasi, (3) menjelaskan dan praktek pembuatan kerupuk pastar. Setelah melakukan penyuluhan maka di hari berikutnya tim pengabdian melakukan diskusi dan tanya jawab cara pembuatan kerupuk pastar berkualitas. Dengan menggunkan prosedur yang telah dibahas dan dipelajari maka dengan dibimbing oleh tim pengabdian para peserta mampu melaksanakan kegiatan pembuatan kerupuk tersebut secara bersama-sama. 


\section{HASIL KEGIATAN}

Dalam upaya menyampaikan sebuah kegiatan pengabdian pada masyarakat dengan tujuan memberikan penyuluhan dan diskusi tentang cara pembuatan kerupuk berbahan dasar ampas tahu, maka ada 3 kegiatan utama yang dilakukan, yaitu (1) Penyuluhan, (2) pembuatan kerupuk serta (3) Diskusi dan tanya jawab.

\section{Penyuluan}

Kegiatan penyuluhan merupakan kegiatan yang disampaikan Tim Pelaksana kepada masyarakat terutama ibu - ibu yang memiliki industri tahu. Kegiatan ini diawali dengan membagikan produk kerupuk pastar yang sudah jadi untuk memotivasi peserta kegiatan. Penyuluhan dilakukan di rumah Ketua Kelompok Pengrajin Tahu Gerimak Ibu Siti Faizah dengan dihadiri oleh kurang lebih 15 orang. Kegiatan yang dilakukan adalah sebagai berikut: (1) Menyampaikan manfaat ampas tahu sebagai bahan makanan yang bernilai ekonomis, (2) Menyampaikan cara pembuatan kerupuk meliputi, penyiapan bahan baku, pencampuran bahan - bahan, pencetakan adonan, perebusan, pemotongan, penjemuran, pengemasan, penggorengan,

\section{Proses Pembuatan Kerupuk}

Tim pengabdian bersama masyarakat melakukan kegiatan praktek pembuatan kerupuk dari peyiapan bahan, proses pembuatan, dan penjemuran. Dari kegiatan ini dapat diperoleh hasil sebagai berikut sebagaimana tercantum pada gambar 1 dan 2
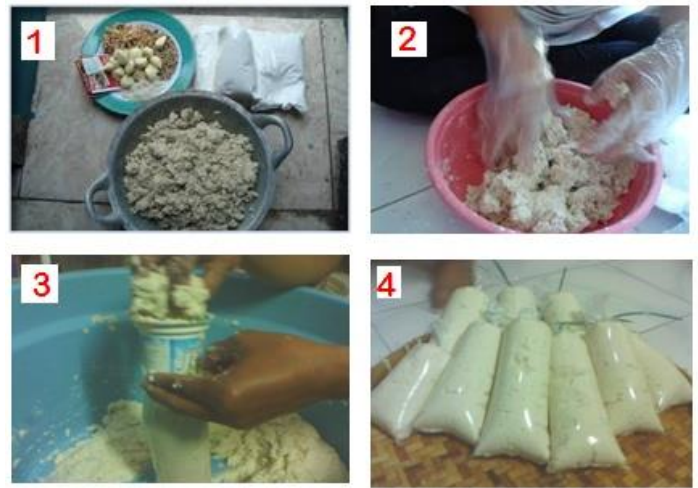

Gambar 1. Proses pembuatan kerupuk
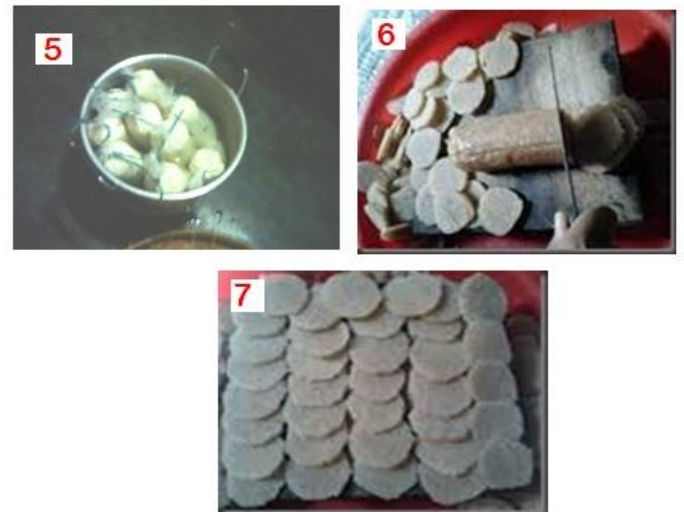

Gambar 2. Proses lanjutan

\section{Diskusi dan Tanya Jawab}

Diskusi dan tanya-jawab merupakan kegiatan yang paling utama dalam kegiatan pengabdian ini, sebab dengan diskusi ini, tim pengabdian dapat melakukan evaluasi hasil praktek dan juga pendapat-pendapat masyarakat yang diinginkan. Sebelum diskusi dimulai, maka terlebih dahulu dibagikan kerupuk yang telah dibuat untuk selanjutnya dibahas apa kekurangan dan kelebihannya. Dalam kegiatan diskusi dan tanya jawab ini dapat dihasilkan beberapa pendapat, saran, pertanyaan atau masukan sebagaimana tercatum dalam tabel 2. Secara fisik kegiatankegiatan diskusi dapat dilihat dalam gambar 3 berikut:

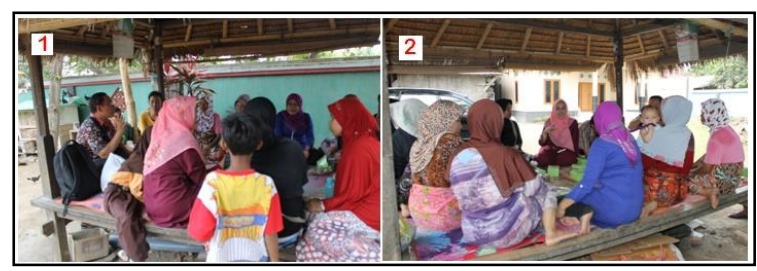

Gambar 3. Suasana kegiatan diskusi dan Tanya masyarakat dengan Tim Kegiatan

Kegiatran ini bertujuan menggali pendapat masyarakat terhadap hasil kerupuk yang telah dibagikan atau pendapat lain yang terkait dengan kerupuk dengan bahan dasar ampas tahu. Dari kegiatan diskusi dan tanya jawab dapat diidentifikasi beberapa hal yang terkait dengan kegiatan pembuatan kerupuk berbahan dasar ampas tahu sebagai berikut.

1. Tanggapan peserta: sangat senang dan tertarik karena sudah sejak lama menjadi harapan masyarakat lama untuk memanfaatkan ampas tahu. 
2. Tanggapan peserta: Kerupuk yang di buat didinilai lebih berkualitas dari kerupuk yang selama ini mereka buat dan ada harapan untuk dikembangkan sendiri dan dijual

3. Pertanyaan peserta: Apakah bisa kita tambahkan bumbu penyedap atau lainnya dalam pembuatan kerupuk, sehingga memiliki rasa yang lebih sesuai dengan keinginan masyarakat umum?

4. Pertanyaan peserta: Apakah disamping kerupuk kita juga dapat membuat jenis makanan lain dengan bahan dasar ampas tahu? dan apakah rasanya bias ditambahkan penyedap rasa seperti vitsin dll.

5. Tanggapan dan jawaban Tim (1): Sesuai harapkan dari kegiatan ini yaitu ibu - ibu mendapatkan wawasan baru atau apalah yang penting dapat meningkatkan kreativitas dalam menggunakan ampas tahu sebagai bahan makanan yang berkualitas (kerupuk).

6. Tanggapan dan jawaban Tim (2 dan 3): Harapan kami tidak menggunakan bumbu penyeda dan, bahan pengembang ini bertujuan agar ibu $-i b u$ dapat mengembangkan/kreativitas sendiri sesuai dengan selera masyarakat konsumen. Untuk menambah kualitas rasa dapat dilakukan dengan: (1) bumbu bawang, garam, roiko bisa ditingkatkan jumlahnya, (2) penggunaan bumbu masak vitsin diperbolehkan asalkan tidak berlebihan, (3) bahan pengembang diperbolehkan agar terasa lebih renyah, (4) bisa ditambahkan cabe agar terasa pedas.

7. Tanggapan dan jawaban Tim (4): Ada beberapa bahan makanan yang dapat dikembangkan dengan bahan dasar ampas tahu, yaitu tempe gembus dan kecap.

8. Tanggapan- saran peserta: Berharap kegiatan ini dilanjutkan dengan produk yang berbeda dari bahan ampas tahu.

Berdasarkan data tersebut, masyarakat sangat antusias dan memiliki semangat yang tinggi untuk mengembangkan usaha ini. Akan tetapi juga secara tidak tertulis dalam pelaksanaannya masyarakat tetap mengharapkan bimbingan Tim pengabdian.

\section{KESIMPULAN DAN SARAN}

Dari hasil kegiatan pengabdian masyarakat ini dapat diambil beberapa kesimpulan, yaitu:

1. Telah dilakukan pendampingan dan penyuluhan tentang cara pembuatan kerupuk dengan bahan baku ampas tahu dengan hasil masyarakat sangat tertarik dan termotivasi

2. Telah berhasil dibuat kerupuk berbahan dasar ampas tahu, Hasil evaluasi produk kerupuk oleh masyarakat menunjukkan bahwa untuk meningkatkan kualitas rasa, maka perlu ditambahkan bumbu masak seperti bawang.

3. Telah dilakukan diskusi dan tanya jawab dengan hasil masyarakat termotivasi untuk membuat kerupuk tersebut dan menginginkan inovasi yang terkait dengan rasa (gurih atau pedas). Disamping itu hasil diskusi juga menunjukkan keinginan masyarakat untuk senantiasa dibina dalam mengembangkan bahan makanan berbahan dasar ampas tahu

\section{UCAPAN TERIMAKASIH}

Ucapan terimakasih kepada BP3F FKIP dan Lembaga Penelitian dan Pengabdian kepada Masyarakat Universitas Mataram yang telah member segala fasilitas untuk kegiatan ini.

\section{DAFTAR PUSTAKA}

Badan Pusat Statistik Indonesia. Diakses tanggal 05 Mei 2019.

Dewi, M.U; 2017, https:// beritagar .id > artikel > sains-tekno > pemuda-ntb

Dwi, R.A., 2017, Analisis Keuntungan Dan Kelayakan Usaha Pada Agroindustri Tahu Tempe ((Studi Kasus di Kelurahan Kekalik Jaya Kota Mataram).

http://www.menlh.go.id. Informasi Praktis Pengelolaan dan Pemanfaatan Limbah Tahu Tempe.

Mariatun Mariatun dan Harry Irawan Jauhari, 2020, Studi Sanitasi Industri Rumah Tangga Dalam Pengelolaan Tahu Tempe di Kelurahan Kekalik Jaya Kecamatan sekarbela, GEOGRAPHY : Jurnal Kajian Penelitian \& Pengembangan Pendidikan Vol 6, No 1 (2018): APRIL 34-44

Nur Azis Rohmansyah, Pemberdayaan Masyarakat Melalui IbM Pelatihan 
Jurnal Pengabdian Inovasi Masyarakat Indonesia, 1 (1), 2022 - 5

Muti'ah, Siahaan, Junaidi, dan Sukib

Olahan Limbah Tahu di Desa Drono Ngawen Klaten, JKB Vol. 21. No.XI. Desember 2017, 42-48

Sayow, F dkk $\cdot 2020$. Pengelolaan Industri Tahu. http:// environmentalpublic. blogspot. com/ 2012/03/ pengelolaanlimbah-industri-tahu.html. Jurnal Ilmiah AgrisosioekonomiUnsrat Vol 16, No 2 (2020) $245-252$
Pusbangtepa. 1989. Tahu, tempe, pembuatan, pengawetan, dan pemanfaatan limbah. Pusat Penelitian dan Pengembangan Teknologi Pangan, IPB

Putra,Y.M,2012.https://republika.co.id/berita/ $\mathrm{m} 7 \mathrm{o} 4 \mathrm{vw} /$ besok-lima-ribu-pengusahatahutempe-mogok-produksi Selasa $24 \mathrm{Jul}$ 2012 